\title{
Forms of subjectivation: Generation Y and the contemporaneity
}

\author{
Formas DE SUBJETIVACIÓN: GENERACIÓN Y Y LA CONTEMPORANEIDAD
}

André Verzoni; Carolina Lisboa

Pontifícia Universidade Católica do Rio Grande do Sul; andre.verzoni@gmail.com

\section{Historia editorial \\ Recibido: 16-05-2015 \\ Primera revisión: 03-05-2016 \\ Aceptado: 10-09-2016}

\section{Keywords}

Forms of subjectivation

Generation Y

Contemporaneity

Youth

\begin{abstract}
This empirical article is a result of a qualitative, exploratory and cross-sectional research in which we investigate the forms of subjectivation of the young people of Generation Y. Though the concept that seeks to describe the contemporary youth disregards some specificities, it can be useful and unravel subjectivities. In this exploration, theories of contemporary subjectivity and the psychoanalysis provided a large perspective. To achieve the purpose of the research, semi-structured interviews were performed with six youngsters with the themes: work, interpersonal and virtual relationships, self-image, routine, ethics, idols, violence, consumption, goals and critical opinion about society. The method used to analyze the interviews was the Interpretative Analysis of Frederick Erickson. The main conclusions were that these youngsters want to participate in a project in which they can provide a subjective contribute; present ambivalence, characteristic condition of adolescence; demonstrate conflicts about a cultural requirement that demands a constant individual development.
\end{abstract}

\section{Resumen}

Palabras Clave

Formas de subjetivación

Generación Y

Contemporaneidad

Juventud
Este artículo empírico es el resultado de un estudio cualitativo, exploratorio y transversal en el cual investigamos las formas de subjetivación de los jóvenes de la Generación Y. Aunque el concepto que pretende describir la juventud contemporánea desconsidere algunas especificidades, esto puede ser útil y revelar subjetividades. En esta exploración, teorías de la subjetividad contemporánea y el psicoanálisis proporcionaran una perspectiva amplia. Para lograr el objetivo de la investigación, se realizaron entrevistas semiestructuradas con seis jóvenes sobre los temas: trabajo, relaciones interpersonales y virtuales, autoimagen, ética, rutina, ídolos, violencia, consumo y opinión crítica sobre la sociedad. El método utilizado para analizar las entrevistas fue el Análisis Interpretativo de Frederick Erickson. Las principales conclusiones fueron que estos jóvenes quieren participar en un proyecto en el cual pueden ofrecer una contribución subjetiva; presentan ambivalencia, condición característica de la adolescencia; demuestran conflictos referentes a la demanda cultural que requiere el desarrollo individual constante.

Verzoni, André \& Lisboa, Carolina (2016). Forms of subjectivation: Generation Y and the contemporaneity. Athenea Digital, 16(3), 105-130. http://dx.doi.org/10.5565/rev/athenea.1638

\section{Introduction}

Generation $\mathrm{Y}$ is one of the designations assigned for the contemporary youth. The concept of generation presupposes a categorization, an operation that can create and reinforce stereotypes and disregard specificities. On the other hand, it may enable the discovery and exploration of common characteristics between the members of the group (Bauman, 2011). Considering that one of the main features of present time youth is their complexity (Birman, 2006), the importance of the categorization Generation $\mathrm{Y}$ can be evidenced by the difficulties that this condition imposes. However, it 
may be essential to address the risk of naturalization that this designation may cause. In this sense, in order to make relations between the Generation $Y$ and the youth, it is important to consider the last as a dynamic and historical concept. The stages of development and their chronological and biological determinants must be respected, but it is also necessary to consider the modifications that are imposed by social, cultural and political conditions and their influences on developmental changes (Birman, 2006; Foucault, 1984).

In the contemporaneity, the youth is presenting traits that suggest an extended adolescence. In other words, in the seek to assume adult characteristics, the youngsters may exhibit conflicts, desires and behaviors that characterize the adolescence. In the contemporaneity, compared to other historical periods, the adolescence begins earlier and finishes later (Birman, 2006). The adolescence is characterized by the absence or inconsistency of a life story, condition that would allow the subject to accomplish a detachment from his position and a retreat based in critical capacity. In the contemporary society, the youngsters that try to integrate the context that surrounds them find difficulties to project and construct their own history and future. In this sense, it is important to highlight that there is not just one youth. The contemporary youth comprises different youngsters that, based in the singularity of their histories, interact with social, cultural, sexual and affective factors (Le Breton, 2011). The contemporary youth and adolescence face several impasses. These impasses result from the absence of a stable horizon that would orient strategies and forms of subjectivation that would allow them to deal with the challenges that are required in order to integrate the social space. The imponderable characterizes this attempt of insertion, since youngsters have difficulties finding a reliable way to consolidate an articulation between present and future (Birman, 2013b).

The concept of adolescence dates back to the context of the emerging modernity and industrialization. In the contemporaneity, the increasing time that an individual needs to finish his or her studies and the competition that characterizes the search for employment constrict youngsters to remain dependent on their families and compel them to remain adolescents (Kehl, 2004). Generally, investigations conducted by the human and social sciences indicate that the study of the youth must consider many different aspects, such as socioeconomic status, ethnicity, historical and cultural contexts. This way of thinking is a counterpoint to the ideas of homogenization of the youth in some few aspects (Sousa \& Goldmeier, 2008).

In the beginning of the modernity, adolescence and youth have been condensed in the same concept. The main social and historical characteristic that youngsters share is their need to go through a passage between childhood and adulthood. It is important 
to highlight this dynamic condition as a way to confront the naturalization of the stages of life, which classification is based mainly in the reproductive potential of the individual. In this sense, childhood represents the absence, adolescence corresponds to the urgency, adulthood means the complete usage and the old age characterizes the loss of the reproductive potential. The eminently biological descriptions are important, but in the contemporaneity have been exposed to a severe deconstruction imposed by historical, social and cultural aspects (Birman, 2013b).

\section{Generation Y: ideas and open concepts to study and think about the contemporary youth}

The concept of Generation Y includes in its domain people that were born between 1980 and 2000. The context in which the subjects of this generation live, compared to the world known by their parents and grandparents, offers them more study opportunities and alternatives to enjoy their life. Inserted in this surplus of possibilities, Generation $\mathrm{Y}$ is in danger of losing references about what is essential in their lives. Work, for example, although it is considered important by this generation, does not seem to be among their priorities - especially if the work activity is repetitive, regular and stable (Bauman, 2011).

Among the contemporary elements that can take the place as a primary agent of changes in behavior and perceptions of the Generation Y, are the new digital technologies, especially those related to the Internet. It is important to remember that, among the most exposed to these transformations, are the people born in the late twentieth century (Prensky, 2001). Members of the Generation Y are usually described as optimistic, smart and able to work in teams. In addition, they are recognized for their respect and ability to live with different hierarchy levels and rules (Howe \& Strauss, 2000). In the workplace, these individuals are described as skilled to perform multiple tasks at the same time, self-confident and comfortable to show their qualities. Fame and wealth are ideals to be achieved but, on the other hand, a surprising sense of empathy can lead the Generation Y to carry out social and charitable work. This generation comprises explorers and curious individuals that are always in search of a new job and experiences, a feature that can neglect marriage, children, and the purchase of a home (Alsop, 2008). The Generation Y, or Millennials (Howe \& Strauss, 2000), unlike other generations, seeks to devalue the cynicism and pessimism. Instead, they want to promote collective work, modesty and good conduct - especially if they can be recognized for it. Previous generations expect that Generation Y will be able to exercise leadership roles and achieve social relevance as a result of their exposure to different cultures and forms of knowledge provided by education, globalization and the Inter- 
net. The other generations expect that the Generation $\mathrm{Y}$ will be able to build new structures and institutions, rather than question or destroy them. In this sense, this generation can bring new meanings to the contemporary lifestyle (Howe \& Strauss, 2000).

For the Generation Y, free time, leisure, traveling and time to be spent with friends are priorities. Work must offer long periods of seclusion, possibility to work at home and provide an amusing corporative environment. If a job is considered unattractive and does not offer some of these characteristics, it is likely to be quickly abandoned or replaced by another one, since the threat of unemployment apparently does not frighten these youngsters. However, the context of a wide range of possibilities and freedom, to which this generation is used to, may reveal itself as an illusion. If the consequences of the severe global economic crisis that took place in 2008 keep their course or even get worse, it is likely that the abundant opportunities of employment will not be sustained, a circumstance that will require that the Generation Y develop a significant adaptability. The context in which this generation arose, with unlimited choices - whether realistic or illusory -, security provided by financial credit and wealth to maintain themselves in case of difficulties, could prove impossible. In these new unfavorable conditions, Generation Y would have to perform a difficult transformation and adoption of new models (Bauman, 2011).

It is possible to establish a relation between these ideas that Zygmunt Bauman (2011) developed a few years after the global economic crisis of 2008 and the writing of Civilization and its discontents by Sigmund Freud (1927/1996). The preparation and completion of the Freudian text occurred just before the severe economic crisis of 1929 and the crash of the New York Stock Exchange, as well as the rise of Hitler's party in Germany (Gay, 1988/2008). These inauspicious events illustrate some of the difficulties, regarding the human existence, that Freud explains in his text: the inherent suffering caused by the condition of inhabiting a physical body, the threats and dangers of the environment and the limitations and confrontations present in the relationships between people emerge as inevitable elements of human life (Freud, 1927/1996). In this context, happiness becomes unreachable and the only possibility is to mitigate the effects of the suffering. As a refuge that shelters the subject, culture offers conditions that can decrease the discontent but, on other hand, it demands in exchange the adoption of limits and prohibitions that reach those who wish to become a part of it (Roudinesco \& Plon, 1998). Thus, the forms of subjectivation, that is, ways that are likely to be adopted by the subject to become integrated into the culture are defined and delimited by sacrifices and requirements (Bleichmar, 2004/2010) 
Although subjectivity has this fundamental importance for the viability of the subject's existence, it can be confused neither with the psyche and its inherent complexity nor with the unconscious processes that occupy another layer of the psychic life. Subjectivity is a historical construction that follows the specific characteristics of the place or time in which it operates. More than allowing the entry of the subject in the culture, the stability of the subjectivity sustains it and provides the beneficial organization of the psychic life (Bleichmar, 2004/2010). The forms of subjectivation, and the malaise that necessarily accompanies them - due to the fact that the subject must dismiss something of his own to be part of the culture (Freud, 1927/1996) - are directly influenced by the historical and social conditions. From this point of view, the knowledge about the forms of subjectivation shows itself vital for psychoanalysis. The study of the subject and its changes over the years, decades or centuries can provide psychoanalysis a constant update regarding its theory and clinical practice (Birman, 2013c).

Culture is fundamental for the understanding of the forms of subjectivation. The Freudian concept of culture consists, mainly, in the acquisitions and developments that distinguish humans from animals. Culture demands obligations and offers rights for the subjects that want to be a part of its context. The benefits lie in the control of nature and its inherent instability and constant change, a condition that offers some security to the participants of civilization. The obligations reside in the restriction of individual freedom and the acceptance of moral and cultural imperatives. The culture, to protect itself against individual interests that threaten the status quo, has institutions, laws and cultural customs that enable its maintenance (Freud, 1927/1996).

The concept of the subject is not directly present in Freud's work. It was Jacques Lacan (1953/1998) who introduced the concept of subject in psychoanalysis to formulate the idea of the subject of the unconscious. In his reinterpretation of Freud's texts, Lacan used the philosophical discourse to make this theoretical breakthrough (Lacan, 1953/1998). Although the word subject was not present in Freud, the forms of subjectivation are part of the Freudian theory and his exploration of the psyche (Birman, 2013a). For psychoanalysis, the greatest importance lies with the unconscious processes and their specific rules. Subjectivity, in turn, has the vital function of providing stability to the subject's psyche in its relation with the space-time in which he inhabits. Even if they are - to some extent - unpredictable, the unconscious processes obey some general rules. The forms of subjectivation are more malleable in structural terms, since they are sensitive and react directly to the historical and cultural changes (Bleichmar, 2004/2010).

The study of the concept of forms of subjectivation, that is, the investigation of the forms that can be adopted by the subject to be part of different cultural and histor- 
ical contexts leads to Michel Foucault (Potte-Bonneville, 2004). The development of the subjectivity is characterized by a search and questioning, carried by the subject, about the ways that he can lead his life through the culture. This construction requires improvement and reflection about the norms and cultural customs and habits, a circumstance that forces the subject to perform a moral exercise. Confronting himself with a cultural imperative, the subject is constrained to think about himself. The result is the emergence of the forms of subjectivation (Foucault, 1984). Didactically, the field of forms of subjectivation can be seen as a confrontation - and an agreement - between two opposing parties: the subject and the culture (Weinmann, 2006). The forms of subjectivation allow the inclusion of the subject in the culture, enabling the creation and development of a specific style of existence (Birman, 1997).

\section{Contemporaneity and forms of subjectivation}

Among the main characteristics of contemporaneity, draws attention the increasing speed of the changes carried by the forms of subjectivation, which in turn demands a constant renewal of theories which intend to describe and understand them (Bauman, 2001). Since its inception, psychoanalysis seeks to adopt clinical models that are consistent with the characteristics of the time and culture in which it operates. The psychoanalytic practice, to keep itself relevant, should be based on theoretical elements that are connected with the new psychic conditions. These models cannot be arbitrary, but must be drawn from the forms of subjectivation of the time in question (Birman, 2013c).

In contemporary times, narcissism and the primacy of the image occupies a prominent place in the forms of subjectivation. The intersubjective exchange, living with and tolerating differences, becomes increasingly scarce. To have comes to occupy a prominent place and reduces the space of being, since it is more important to triumph in the direct dispute and comparison to others than to obtain a satisfaction that is proper to the subject. In this self-centered environment, human relations become increasingly impoverished, superficial and fleeting, a circumstance that increases the isolation of the subject (Dockhorn \& Macedo, 2008). The subjectivity of contemporaneity is characterized by the worship of appearance and the overvaluation of aesthetics. Paradoxically, the search for the gaze and admiration emerges as a way to compensate the structural deficiencies of the contemporary subject, the result of a narcissistic investment that favors the image and superficiality (Birman, 2007a; 2013b). Recognizing these conditions, psychoanalysis should be able to defend the uniqueness of each subject and simultaneously offer space and means for the development of psychic and interpersonal skills. Staying true to its origin, psychoanalysis should enable reflection, 
psychic work, construction and enrichment of intrapsychic and affective involvement with the other (Dockhorn \& Macedo, 2008).

The contemporaneity - just one of the stages of modernity - can be considered, among other factors, a consequence of some events that took place in the end of the twentieth century: the pursuit of equalization of rights and decrease of differences between people, expansion of social exclusion and globalization (Birman, 2013a, 2007a). The modern times are characterized by the decline of collective and community ideals, the rise of individualism and the abandonment or weakening of the rules that guide the lives of the subjects (Bauman, 2001). In contemporary times, adolescence and youth are blended and it becomes increasingly difficult to tell them apart. This overlay is based on a feature shared by both phases: uncertainty and ambivalence. In this context, the future becomes unpredictable and ideals become unstable (Birman, 2013b).

Since the integrants of Generation Y represent a significant amount of the world's population and a considerable force in vital fields - academic, organizational and social (Alsop, 2008; Howe \& Strauss, 2000; Stein, 2013) -, it can be assumed that this generation has a considerable importance on the new forms of subjectivation. In order to formulate and consolidate their different subjective styles (Birman, 1997) these youngsters seek their way through the culture.

\section{Participants}

Although the year of birth between 1980 and 2000 is the range indicated by most au thors to define Generation Y (Alsop, 2008; Bauman, 2011; Howe \& Strauss, 2000; Prensky, 2001; Stein, 2013), on this study were included only individuals who, at the time of the interview, were between 20 and 25 years old. The reason for establishing this limit was to prevent the large amplitude provided by the age group established by the authors to designate the Generation Y. This specific range (20-25 years old) was also chosen because of its prevalence in the Brazilian population pyramid (Brazilian Institute of Geography and Statistics [IBGE], 2010). To be included in the research, the participants had to be employed at the time of the interview, in order to contribute with this theme. All participants belong to high social and economic levels, with monthly family incomes that characterize A and B classes - A stands for more than $R \$ 11,262$ (brazilian reais) and $B$ from $\mathrm{R} \$ 8,641$ to $\mathrm{R} \$ 11,261$ (Secretary of strategic subjects [SAE], 2014). Were privileged professions that are linked with contemporary technologies or connected to a need of constant renew. Psychologists or undergraduate psychology students were not included in the research to avoid reflections and possible biases related to theoretical knowledge on the subject of research. 
Information about the participants is the following (participants / age / occupation. Names assigned to participants are fictitious):

- Angelo / 24 / Adman

- Leonardo / 22 / Director of technology

- $\quad$ Rafael / 20 / Scene director (movies)

- $\quad$ Emilia / 24 / Teacher/museum guide

- Paula / 25 / Architect

- $\quad$ Claudia / 25 / Adwoman/Image editing

\section{Methods and procedures}

This article is based in a qualitative, cross-sectional and exploratory research that established as objectives the exploration and investigation of the forms of subjectivation of Generation Y. To achieve this purpose, this study used the Interpretative Analysis methodology (based on theories of forms of subjectivation and psychoanalysis). This method proposed by Frederick Erickson (1986), searches and explores universal interpretations to specific phenomena. The Interpretative Analysis does not apply to the production of universalization towards statistical generalizations. The interpretative method operates from case studies that are analyzed in depth and detail. Each case is considered individually and, after, comparisons can be made between different cases. The interpretative research seeks, above all, to contrast different surfaces and layers of universality and particularity that are presented in each case. The universality overflows the specific case and may be related with other cases, while the particularity is unique and is limited to its original context. The interpretative method allows the proposition of assertions, which may be accompanied by parts of the interviews. Assertions are statements about the phenomenon under investigation. They are produced from the several senses present in the speech of each participant and their relations to the other cases. The main objective of the interpretive research is to deepen, extend and explore the phenomena and obtain, as a result of the investigative effort, the creation of assertions (Erickson, 1986). Studies on Generation Y, theories of contemporary subjectivity and psychoanalysis served as basis for interpreting the various layers of the narratives, create the assertions and guide the researcher in the seek of universality and particularity. 
After the approval by the Research Ethics Committee of the Pontifical Catholic University of Rio Grande do Sul (PUCRS) (number 622,051), the scheduling of the interviews with the six participants (three men and three women) started. Participants were contacted from the indications provided by people of the researcher's relationship circle. After a friend request made through Facebook, the private messaging tool of the social network served as an initial communication for scheduling the interviews. The meetings lasted 40-60 minutes and took place in reserved places. The Terms of Consent were signed by the participants. All ethical guidelines were followed, and the anonymity of the participants was maintained. The semi-structured interviews respected the axis of topics that were drawn from the theoretical references and the research objectives. The exploratory guidelines included the following topics: work, interpersonal and virtual relations, self-image, time (routine), ethical values, idols (celebrities), violence, consumption, goals and critical opinion about contemporary society. It was offered to the participants the possibility of bringing topics of their personal interest. The original dialogues, all in Portuguese, were recorded, transcribed and the extracts that are present in this article were translated to English. Each participant was identified with a fictitious name designated by the authors of the research.

\section{Results and discussion}

After the analysis of the six interviews, four assertions were formulated about the subjectivity of Generation Y.

First assertion: the youngsters of Generation $Y$ demonstrate psychological distress or reflections caused by the requirement of reaching a way of life consistent with the culture

To integrate a particular culture, the subject is constrained to accept specific individual sacrifices (Freud, 1927/1996). The forms of subjectivation, a composition that takes place between the subject and the rules that are imposed culturally (Foucault, 1984; Potte-Bonneville, 2004; Weinmann, 2006), are vital to the subject, since they have the ability to protect and balance the instability of the unconscious processes (Bleichmar, 2004/2010).

In some excerpts, Angelo talks about his quest to reach a life coherent with cultural context:

It is time to create your own style in personal life, at work, in any of your choices, these are things that become a kind of definition, so in the future 
you can slow down. (...) These are things that seem like a step to more fixed things (...) it is an anguish that I know that only time will define, but these are things that I have to think about all day long (...) I have this pressure. If I had a son here, he would have to go to a private school, live an experience in another country, he must have these things. (Angelo, personal interview, May 29, 2014)

The anguish reported by Angelo increases as the forms of subjectivation encounter difficulties to face and match with the cultural requirements. In this regard, freedom and the significant amount of options available to the contemporary subject can cause even more suffering and doubts, since they cannot always find the ways to take advantage of these features (Roudinesco, 2000). Angelo presents uncertainties about the directions that he will take in his life and suffers because of that. In his speech, it is possible to see the conflict related with the choices and their inevitable losses, since just a few of the opportunities that are within his reach can be enjoyed throughout life. The contemporaneity, named by Bauman (2001) as liquid modernity since is characterized by mobility, transience and the vast quantity of forms of subjectivation - seduces the subject with the possibility of self construction and the possibility of choosing his own lifestyle.

In contemporary times, one of the biggest fears that may affect the subject is the possibility of inadequacy. If the subject does not have the ability to adapt to specific cultural circumstances, the conditions of inutility and failure may fall over him. Due to the predominance of individualism, the responsibility of becoming and staying productive, and enjoying all the possibilities that are available, lies almost exclusively on the subject himself (Bauman, 2009). In the words of Angelo, the conditions and possibilities available for him may become intolerable or excessive:

Yes, I would like to make money, but I don't care that much about it, but of course I will pursue it forever. I think about traveling to a place where it's not necessary to have as much money as it's necessary here. Because I come from an upper-class family in Brazil, but also not very rich, anyway, I have to, at least, maintain my standard of living. (Angelo, personal interview, May $29,2014)$

The desire to travel or live somewhere else emerges as a way of rejecting the cultural and parental demands that requires that Angelo, at least, maintain his standard of living and the material and social conditions that were given to him. Traveling can mean freedom from the demands of a life full of obligations:

I trust myself, but this is not the environment that I wanted to live in (in Brazil and the city of Porto Alegre). Yes, I have traveled to some places, then 
I felt that, you know, there are places that ... and this thing of travelling is a favorite thing to do. (...) It is a very important thing to travel. Just to enjoy, just to enjoy it. (Angelo, personal interview, May 29, 2014)

The culture, although predominant in relation to the subject, reserve space for him to - from the inconsistencies, failures and contradictions of the context of civilization that surrounds him - propose new forms of subjectivation (Bleichmar, 2004/2010; Freud, 1927/1996). In this segment, it is possible to see how Rafael face the cultural demands that he apprehend:

I think that the great challenge of living in this society is the requirement of having to get somewhere (...). It is a thing of the capitalism that forces you to consume. And it's something that capitalism implies: you must have purchasing power. (...) So, from an early age the child already wants to have things, it reflects after in the choice of the profession when he is eighteen years old. You must have a doctorate, a master's degree, you must have it. But these goals are quite... I do not know, they will be easily modified with the passage of time. Today you want something, two years from now, you no longer want it. So, people, instead of demanding themselves to go somewhere, they demand themselves to get somewhere. (Rafael, personal interview, June 12, 2014)

Although present some signals of a subjective model characterized by the self construction (Bauman, 2001), freedom, individual autonomy and narcissistic valuation of the subject (Kehl, 2002), Rafael promotes a reflection about the contemporary subjective possibilities. His personal construction favors the search of the singularity of the subject. The words of Rafael highlight the importance that he assigns in following his own path. For him, this is the scenario in which the subject can search the composition between his uniqueness and the cultural demands: the trajectory is the very reason of the existence of the subject.

For Emilia, the achievements that a person reaches during his life is directly related to what the context might have offered:

Often (a person) only looks for himself, he or she doesn't realize that the merit is not entirely hers. (...) It is the person's own environment, her social position and the opportunities they had, the merit doesn't belongs only to them, that were facilities of life, of the conditions. (Emilia, personal interview, July 5 , 2014)

In contemporary times, the overvaluation of the self takes on new settings relatively to what it represented in the beginning of modernity. Before, the inwardness was allied to reflection (Birman, 2007a). Nowadays, however, the ability of the subject 
to question and think about himself in relation to his cultural and family context is in decline (Dockhorn \& Macedo, 2008; Melman, 2002). Emilia, however, does not express this form of subjectivation that limits the subject. She offers reflections and asks questions about this matter. Nevertheless, Emilia does not observe, in most people, this way of thinking and acting characterized by critical capacity and identifies the predominance of the overvaluation of individuality. The narcissistic misappropriation described by Emilia can lead to a dangerous psychic condition. Since the subject holds all the merits, it is reasonable to assume that if he does not reach what he expected, the consequences of failure may fall over him in an excessively or even exclusive way (Bauman, 2009).

For Angelo, cultural and parental demands can represent a source of psychological distress, although they may be beneficial in order to enrich his subjectivity. Rafael reflects about how the cultural requirements may limit the contemporary subject. For him, the singularity looses its vitality when confronted with some of the cultural imperatives. According to Emilia, the subjects must remember their debt with the culture, instead of only focusing in what it can offer them without demanding anything in return.

Second assertion: want to participate in a project or professional activity in which they can provide an subjective contribute and consider collective and creative work the key to professional achievement

The Generation Y considers their occupation one of the most important ways to achieve something that is relevant for the society in which they live. Among the members of this generation, personal and ethical values are intrinsically linked to the type of work that they want to carry out and the characteristics of the organization and its purposes (Ng, Schweitzer, \& Lyons, 2010). Angelo clearly wishes to participate with his own subjectivity in the construction of a collective, intellectual and not repetitive kind of work. According to Angelo, this is a feature that can also be found among his peers:

For my career I think I feel good where you have more autonomy to do things, where you can use your creativity and think about solutions, do less manual labor. I think that's what makes my eyes shine, and for my colleagues too. (...) I work with planning, I like this area of stepping backwards to step ahead. (...) What makes my eyes shine is opening my own business in the future. (Angelo, personal interview, May 29, 2014) 
Despite respecting the different hierarchical levels and knowing how to respect rules, Generation Y believes that they have the ability to think critically and make changes in the workplace, a characteristic that may conflict with the limits imposed by those who occupy positions of authority (Howe \& Strauss, 2000). For Leonardo, intellectual work has a superior status in relation to the execution tasks that do not require a specific reflection:

I think that, what is cool about engineering, computer engineering, is that besides being focused in technology, it is a much lower level, of how things are built. And engineering, I think, has a very strong connection with the administration too, you know. (...) Because it works with project, it works with the construction of things that you really have to organize and put in practice, you are not just a performer, you know. (Leonardo, personal interview, July 7,2014 )

Generation $\mathrm{Y}$ is described as a group of impatient and ambitious individuals, which may result in frequent job changes. The professional development sought by the members of this generation is characterized by the rush to access higher levels, a feature that can cause difficulties in the regularity and constancy that some occupations may require. The Generation Y imposes itself high expectations and aspires very high goals - objectives that are not always coherent with the effective capacities of some of its members (Stein, 2013). For Leonardo, however, the priority and higher expectations does not relate with professional growth. The possibility of adding something of his own subjectivity to the professional activity is even more vital:

All the time there are people offering you a little bit more so you go and work with them, you know. It is a great auction. But, you know, several times I could have earned a lot more (money). But I always believed that I were in a place where I wanted to be, working with the people that I liked and I felt much better to be chasing something, pushing to go ahead instead of being someone who is just sitting there, waiting for someone to push me, you know? It was, more or less, what I understood. The proximity, to have that freedom to speak, to give an opinion that will change something, to be part of, you know, the company's culture instead of just being there, just carrying it out: sit there all day, do my job, soon I will leave, someone comes in and it stays the same, you know? (...) It is because of what you know, what you believe, and you discuss with people and you get to a consensus, but there is your opinion there, you know, there is a bit of you, of your root. (Leonardo, personal interview, July 7, 2014)

Leonardo seeks to obtain a broad view of his work: he tries to observe the details of each step and their importance, the relevance of his contribution and those made by 
his colleagues. According to Leonardo, a task will only be successful if the people involved give their own personal contributions. Thus, it does not make sense to constantly change jobs, since the exchange presupposes the reconstruction of the space that allows subjective expression and personal contributions. From this point of view, the construction of individual and collective projects in a long term perspective becomes more important than just obtaining immediate financial gains from a new job.

Rafael hopes that, with his work, he will make a contribution to society:

In the work of advertising, I object spending a lot of energy in a job that I thought, I believed, would not leave much to society, would not leave a great heritage. In advertising, you spend a lot of energy making something that, deep inside, you're not really proud of. (...) It is transitory, I think that advertising passes without leaving any value as well. (Rafael, personal interview, June 12, 2014)

For Rafael, transient works have less importance and represents a waste. For Rafael, the main sense of work lies in the originality that it can represent - the subjectivity should not be wasted on tasks that do not contribute with something new and socially relevant. For him, his original contributions would be better employed in the production of documentaries:

I don't think much in an economic development, I think in the evolution of prestige, to be a documentarian. I do it today, do content, because I think it is the easiest way to reach (people), the documentary form. I wanted to be a documentarian, I like documentaries, I am interested in documentaries and I think that being a director of documentaries would be something, I don't know, I think in this way I can contribute to society somehow, in the formation of the society. (Rafael, personal interview, June 12, 2014)

The contemporary forms of subjectivation are characterized by the predominance of individuality. In this context, it is essential to the subjects their narcissistic valorization by the eyes of others (Birman, 1997, 2007a). The primacy of individuality appears in Rafael's speech and serves as the basis for the creation and execution of a work that is relevant to other people. The financial value appears in a lower place when compared with the social recognition. Common and temporary works are considered insufficient to cover the richness of the subjectivity.

Due to the transitory nature of the contemporary subjectivity, the subject finds difficulties to follow their movements and transformations (Bauman 2001, 2011; Birman, 2007a; 2013c; Bleichmar, 2004/2010). In this scenario, the subject looses himself in a context of universal comparisons - which challenges his subjectivity, his material 
and financial conditions, his social and professional level -, and no longer restricts himself to the parameters of the social groups in which he lives (Bauman, 2001). As a response to this lack of external and internal references - which causes psychic fragility - the constant affirmation and validation of the subjectivity are permanent demands of the subject (Melman, 2002). In the words of Rafael, the kind of work that he considers most important - the realization of documentaries - appears as the major mean to validate and consolidate his subjectivity in the culture (Bleichmar, 2004/2010). The desire for prestige, however, assumes a higher character: financial return and transitory works are not enough, the production must present, in a solid way, the subjectivity. This narcissistic satisfaction, however, finds a softening since it is justified as a contribution to society.

Emilia considers her ability to produce something original from the influences that surround her as a fundamental capability:

I want an academic career too, so I always try to read as much as possible, not only in my area, but on other areas that I think are also related, that I can draw a parallel with. I always try to do my best, I try to produce something that is unique too, I try not to stay just on other things, copying, I try to adapt my way of being into my work. (...) This really enhances my desire of being a teacher because, in theory, better education makes you have a more sensitive thinking, more critical. And often, people that would have access, like some people who grew up with me, studied in a private school, who have always had easy access to the university, knowledge, books, internet and culture don't think critically about things. I think that education really must stimulate it and it is something that I value a lot as a teacher. (Emilia, personal interview, July 5, 2014)

As a way of insertion of the subjectivity in the culture, Emilia proposes the appreciation of the inwardness and reflection, elements that are weakened or set aside by the advent of modernity (Birman 2007a). Emilia expresses her desire to share with others, working as a teacher, an important feature of her subjectivity: the ability to think for herself. Therefore, does her best to share with others the possibility of producing something original.

In the speech of Claudia, it can be observed the importance of colleagues for her work:

It is very good to do my own schedule as a freelancer and having my own agenda. But I think that this is not a thing for a very long time. I plan, I want to work in group again. I want to have exchanges, because when you are doing a job and you are the only one looking at it, it comes out in a way. When 
you have someone to give an opinion, an eye that is not narrow-minded, it is much better. So my idea is to have a team that I think is cool again, and do greater jobs. (Claudia, personal interview, July 29, 2014)

For Claudia, the satisfaction with the occupation is directly related to the exchange of experiences. (Alsop, 2008; Howe \& Strauss, 2000; Stein, 2013). In this sense, Claudia shares the condition of great capacity to work in group described as a major characteristic of Generation Y.

According to Angelo, to be interesting, a job should provide the possibility of a collective construction. Ideas and reflection are valued, while repetitive and manual activities are considered inferior. As well as Angelo, Leonardo prefers to be included in ideas and plans that are shared in a context of plurality, especially when there is the possibility of making contributions from his own subjectivity. Rafael considers that his work must express his subjectivity in a massive way and provide a relevant contribution to others. Like Angelo and Leonardo, Rafael considers superficial and transient work a waste that should be avoided. Emilia searches in her profession the means to create new ideas and concepts - and the possibility of sharing these constructions with other people. Claudia, in turn, favors the coexistence and the exchanges with colleagues.

\section{Third assertion: the young people of Generation $Y$ present emotional ambivalences, a characteristic condition of adolescence}

Adolescence can be described as the stage of life in which the subject is suspended, a condition that fills the choices with ambivalence (Birman, 2013b). The subjective style (Birman, 1997) adopted by Angelo, his quest to reconcile his individuality with the culture, is still in the cocoon, that is, waiting for hatch, a circumstance that shows the immaturity experienced by Angelo:

My colleagues (of work), who may not have much, aren't directly attached to financial values (...) they don't pay their own bills, don't have a very clear idea of the real value of things, monetary, but have life goals: an apartment, a car, schools, child, family, goals. (...) Despite going after it, I think that only when you really come out of the cocoon, when you're really independent, things start to take shape. (Angelo, personal interview, May 29, 2014)

The next extract of Angelo's interview presents reflexes of the description of modernity in which it is characterized as a period where the subjects place their professional practice above basic human needs such as relaxing and sharing experiences with friends or family. Thus, the image of the organic machine, tough and tireless fac- 
ing the work requirements, becomes an ideal to be achieved (Birman, 1997). In Angelo's speech, goals and objectives are always present, but the means to do so, the necessary dedication and abnegation - that were transmitted by parents - are not included in the plan to achieve the ideals. Instead, the anguish of ambivalence proliferates:

I feel that what distresses me the most today is to define exactly what I want, if I want to live here, if I want to travel, if I want to stay with my girlfriend, if I don't want to be with her, these are things that seem like a step for things that are more fixed. (...) I think there's a tendency, nowadays, to enjoy life and worry less about obligation, so I think that's it, basically. I see my parents' generation, for example, there was this career thing, work, family (...) if they needed to take ten thousand shifts a week at the hospital, they would do it. I don't have that perception. (Angelo, personal interview, May 29, 2014)

Among the attributes of contemporaneity, can be emphasized the decrease - or even disappearance - of the differences between adolescence and adulthood (Birman, 2007b). Leonardo notes that most of his friends, even though they're working, are not concerned about what they will be able to build throughout their lives and also have difficulties to make decisions:

I think people are very influenced, you know, and do not have maturity to make the decisions. I think that people at 22, 23 years old are not being able to make decisions yet, you know. (...) The majority of my friends - it is that thing, you know - they work all week, leave work, it doesn't make much difference to them, what they want is to drink on the weekend, to do something like that, you know. (...) They are not too concerned with what will happen in 10 years from now, if you will have a family, if you will have the means, you know, to support a family, if you will have built something, if you will leave something to someone. (Leonardo, personal interview, July 7 , 2014)

For Paula, the fact that she still lives with her parents is related to the priority of her life today: professional growth. In her perception, it doesn't make sense to leave her parent's house right now, since this condition offers her more favorable means to dedicate to work. Although Paula mentions the independence of living alone, she believes that it does not compensate the difficulties that her autonomy would cause to the professional routine:

For example, if I live, if I lived alone, I would have more independence, you know? I would do things my way and all, but for me, for now, it is more important to establish myself professionally and have that support at home 
than just leave home only to live alone, you know? (Paula, personal interview, July 19, 2014)

The search for balance between the different spheres of life - work, leisure, family, study -, a characteristic assigned to Generation Y (Alsop, 2008), is present during Paula's speech. However, this balance tends to lean towards the work sphere, at the expense of the independence from her family. The adolescent condition of dependency towards the parents remains, even if it is attenuated - or even justified - by the per spective that this could facilitate the consolidation of an independent lifestyle in the future.

Claudia talks about how much she considers herself different from the adults, who are responsible and dedicated, although she admires these features. In Claudia, some of the features that are commonly attributed to Generation Y - mainly the egocentrism and arrogance (Stein, 2013) - do not show up. However, it is possible to ob serve the high demand of achievements that this generation assumes (Alsop, 2008), although attenuated and manifested as admiration and comparisons to other people, in this case parents and work colleagues:

In fact, the people I admire the most are the most dedicated people. My parents, sometimes, I wonder: "they are too dedicated". More motivated than me, and I'm younger. (...) More discipline, for example, they don't stop. Sometimes you say something at the end of the day, you're already exhausted, and they are still doing something else to you, you know. It is not for them sometimes, it's an extreme dedication, it's their job, or for the people who are around. So, it's always like this, someone more dedicated than me, someone who does an amazing illustration, some work that I love, that I crave to work someday, someone that runs, because I still cannot run. (Claudia, personal interview, July 29, 2014)

Claudia constantly mentions her parents as references to be followed and how much she feels different from them. This great admiration, surprisingly, contradicts one of the conditions described as a characteristic of contemporary subjectivity: the interruption of transmission between generations and the isolation of both parties (Kehl, 2002). In this case, the opposite happens, the parent's constant presence emerges as a source of inspiration and admiration.

As well as Angelo and the descriptions of Leonardo about his friends, Claudia shows that her subjective style (Birman, 1997) is in full expansion. For Paula, maintaining the adolescent condition and the dependence towards her parents is justified because her priority is career advancement. In the speech of these participants, it can be seen how much they consider themselves different from the adults and think that 
they should take more responsibilities. However, the ambivalence is massively present in this process. As a way of defending themselves when facing their subjective task, the youth of Generation Y may present rigidity and contradictions.

\section{Fourth assertion: express conflicts and reflections about a cultural requirement that demands a constant professional and individual development, renovation and the need to take every opportunity}

Leonardo reports some signs of pressure due to the constant evolution that can threat the subjects of the contemporary society (Bauman, 2009):

When I am busier, as it has been in recent times, that I work on Saturday, on Sunday I usually stay at home resting, or you don't enjoy it so much because, otherwise you sleep too much and then you stay at home resting. It is nice to rest but, until which point is it necessary to rest that much, you know? (...) I think it is a kind of waste, even sleeping is a bit of a waste, but we need it, you know? (...) This friend of mine who went to Switzerland now, I met him when we were about 19 years old. He is a guy that came from the coast, so he didn't live in the city and he had a very shallow view of life, you know? He was happy with just a few things, he did not care so much about what he did, and he started to date and the relationship made him grow. (...) To have ambition, to care for things, to create that and today he is a smart guy, you know? He evolved as a person. (Leonardo, personal interview, July 7, 2014)

Leonardo seeks the development of his professional and emotional life and identifies himself with a friend who, from living with someone else, started to have more consistent aspirations from his point of view. The person that takes more responsibility and raises his goals, is seen as a better subject. Thus, resting periods, even if are considered necessary, are related with the waste of time and consequently perceived as mishaps in the professional and personal development (Birman, 1997). This condition remarks how the inadequacy or inability to work and the lack of ambition is something to be avoided, as it may signal the futility of the subject (Bauman, 2009).

In the words of Rafael, it is possible to observe the conflicts that arise from the variety of choices, ways of living and his attempt to orient himself among them:

I don't really know where I want to get, so the important thing is to go. I think the important thing is to face many paths, that you want to go because you are going, and you have to choose. The problem is not to choose wrongly, the problem is not choosing at all. But, nowadays, people value who gets there, and not who is going. It is the immediacy. (...) So it is amazing that half of the choices were not made like this, they were made by this 
pressure. And how are you going to be an artist, artists don't get anywhere. But where does he want to go as a person, you know? It is so bizarre. The guy, he may, as a person, not want to get anywhere. He wants to be self-fulfilled, wants to reach the place that is not the ideal place for you, but it is the ideal place for him. (...) It is amazing how people in this quest to be someone are contented even to be a person a little mediocre, like "I am not doing something that pleases me, but I am being someone for someone else". (Rafael, personal interview, June 12, 2014)

There is something of the essence of the subject that is lost because of the requirements that the culture imposes to include the subject. The subjective challenge is to maintain or find something that represents the real meaning of the subject and that resists the external influences (Birman, 1997; Bleichmar, 2004/2010; Weinmann, 2006). The multiplicity of choices and the fragmentation of forms of subjectivation in several units confront the subjects and threatens their psychic integrity (Birman, 2007a). For Rafael, long-term choices assume a dangerous feature whereas they can be mistakenly defined by the subject, since he does not have the possibility to evaluate, previously, what only experience itself can show or teach to him. Furthermore, very distant goals do not make sense since the subject himself will change and may no longer find the meaning of the path that he decided to tread. However, the absence of a long-term project - paths or objectives that are not restricted to what is within the reach of the subject - can favor the psychic instability and suffering. The absence of a plan or an ideal of life indicates the loss of one of the most vital benefits of adopting a specific form of subjectivation, namely, the protection against the inherent conflicts of the subject facing the demands of the culture (Bleichmar, 1997/2010). As a defense, Rafael maintains that the subject has the right to give up any ideal of life, which may characterize the subjective emptying (Bleichmar, 2004/2010).

To be part of the contemporary culture, the subject must reinvent and sell himself as a merchandise (Debord, 1967/1997). For Emilia, transience, instability and the multiplicity of the subjectivity (Bauman, 2001) challenge the subject:

I think that we really live in this society of the spectacle, that we, I do not know, deal with our subjectivity almost like a merchandise, this sense of, you know, bringing a value that is not subjective, that just stay in the margin and, ultimately, is something that in a way, we sold to the other. As if they (people) were just a merchandise, and they live to have more likes, post more things on Facebook, have more friends, to do things that are cool, to know that band that everyone likes, to have already seen that movie that is not even in the cinema. I think that what is really missing, actually, is experiencing things, giving time for things to happen, the time they need, because, I 
really wonder, what will be left in the end, when things pass, what will be left for these people. (Emilia, personal interview, July 5, 2014)

Appear to be is more important than experiencing something that belongs to the subjectivity (Macedo \& Silva, 2012). Therefore, remaining superficial may represent an advantage in the insertion of the subject in contemporary culture, since it is more important to provide an impression that can be quickly assimilated by others, a circumstance that stimulates the immediacy. The constant need of reinvention arises as a price to be paid by the primacy of the individualism that characterizes contemporaneity (Bauman, 2001; 2009), as well as an imposition of the society of the spectacle (Debord, 1967/1997). Thus, having the chance to live a more authentic experience, that is, with a greater involvement of the subjectivity itself, tends to hold less social value since it can represent an additional difficulty in the task of being presented to others.

In contemporary times, the manifestations of subjectivity tends to be constantly renewed, a circumstance that prioritizes the replacement at the expense of maintenance (Bauman, 2001). In her speech, Claudia reports and criticizes some of the contemporary forms of subjectivation and how they can compel the subject to be permanently reinventing himself. Professionally, the constant renewal appears as a necessity of evaluation that is imposed regarding the quality of the work:

I think that, although what I do gives me satisfaction and everything, I still feel like I need to prove to people. Like, the importance of your work, you have to be always, like, doing spectacular things for these people, they are always asking if I am always working, or doing something that I usually do, and people ask "what is new?", you know? (...) A novelty, you must always be looking for something new. Of course this is good for everyone, to know about new things, I think it gives a nice movement to life but, sometimes, you know, you are just doing normal things. (Claudia, personal interview, July 29, 2014)

The supposed freedom that was offered for Generation Y (Bauman, 2011) stands out as a source of suffering and psychic conflict before the inevitable doubts and failures of the social and professional paths (Melman, 2002). Among the extreme range of choices and the promise of self construction (Bauman, 2001), the subjects can find themselves disoriented in their quest to formulate their subjective style and participate in the culture (Birman, 1997; 2007a; 2013c; Bleichmar; 2004/2010). The lack of consistent references appears in the speech of Claudia:

It's because I think we are, we kind of always heard that we could do whatever we wanted, that we could do things to make us happy, and this possibility to do so many things, let us kind of like this: "wants to do everything, and 
do not know exactly". Wants to do everything, or wants to be the best and you are not always going to be best, you know. (Claudia, personal interview, July 29, 2014)

The speed and the excess of information provided by new technologies, render the virtual environment prevalent, while the local environment looses its importance (Bauman, 2009). In the context of capitalism, a competitive environment is created. And it can turn the other into an enemy that must be fought. Thus, the individualism breaks as a way to upstage others and make the most of every opportunity (Birman, 2013b). Claudia talks about the immediacy, the pressure of a constant renewal and the individualism as a source of problems among people:

I think that, I don't know, this rush for everything, this great offer, it is too much information, everything is a bit exaggerated, the truth is exaggerated, the information is exaggerated, the violence is exaggerated. If things were done with a little bit more of calm, if people could focus on things. Sometimes my mother says: "Oh, you are so quiet, very quiet". But it only gets worse, you know, if you will do something that is not pleasant and it only gets worse, and you will run over. Everything at the right time. It is people always trying to win, without an exchange, without taking other people with them. It ends up being individualistic, people want to get along and forget that everyone can get along. (Claudia, personal interview, July 29, 2014)

Leonardo demonstrates the need to be constantly renewing himself and aspiring new achievements, which may reflect in a conduct that seeks to optimize the time and reduce the periods of rest and recreation which, in turn, are seen as a waste of energy. Rafael has a more critical posture about how to respond to the cultural demand for constant reinvention. For him, the subject needs to be constantly re-evaluating his goals, since these must accompany the subjective changes that occur over time. Emilia highlights the changes that the necessity of constant renewal have on the forms of subjectivation. For her, the need for constant reinvention favors the strengthening of the individualism, immediacy and superficiality, and also favors the weakening of the connection between the subject and the experience. Claudia, in turn, believes that the large amount of possibilities that are available to the subjects of the contemporary time brings doubts and disorientation. Like Emilia, Claudia maintains that the obligation to take advantage of as many opportunities as possible strengthens the individualism of the contemporary context. 


\section{Conclusion}

This qualitative and exploratory study aimed at the investigation and discussion of the forms of subjectivation of the contemporary youth that has been called Generation Y. The interviews with the youngsters allowed the observation and analysis of the specific forms of subjectivation of each participant, as well as the exploration of the modalities of subjectivity that are common among them. The different modes of insertion of these youngsters in the culture present conflicts, unique insights, contradictions, ambivalence, consistency, innovations and new ways to understanding the contemporaneity and the youth.

However, it is worth reminding the limitations of this research. Even though the interviews with the participants were in-depth and detailed, they were carried out with a very limited number of members of this generation. In addition, only people who belong to a specific social, economic and educational background of the country (Brazil) and the city (Porto Alegre) were part of this study. Because of these restrictions about the participants, it is not reasonable to establish generalizations that extend to other contexts.

The extension of the adolescence shows itself as a source of uncertainties for Generation Y. In a sense, the desire for independence and the implication on more responsibilities is clear. From another point of view, however, the sacrifice that these aspirations demand are, on some occasions, avoided or questioned. It is remarkable the ambivalence that concerns the wish to get closer to adulthood and its demands, and therefore disengage emotionally and materially from the parents. These, in turn, are seen as models that are certainly admired, but not necessarily followed. Among the participants, it is possible to observe traces of a suspension state, that they are more convinced of what they want to reach than how they will achieve their ideals and what they will be able to sacrifice to do it.

Among the youngsters that can be included in the Generation Y concept and that were part of this research, it was possible to notice reflections and even psychological distress due to what was offered to them in educational, cultural and financial terms and what they will be able to do with it. This internal conflict can cause discomfort to these youngsters, but it can also enable their improvement in order to reach the maximum of their capabilities. On the other hand, this psychological distress related to the insertion of the subject in the culture can immobilize and inhibit the development of new forms of subjectivation.

Among the participants, it was found that they perceive their occupation not just like a simple employment or obligation. The work constantly appears connected to the 
originality and the subjective specificity of each participant. In the analysis of the interviews, the quest for a professional and personal ideal stood out - not immediate, as the literature commonly proposes - but one in which the subject can contribute with his subjectivity in an activity that involve others. To be valued, the work should be collective, allow individual contributions and serve to a social ideal. Repetitive activities that do not require a specific reflection are devalued. In this sense, some traces of individualism, overconfidence and arrogance, which are usually attributed to this generation, gain strength - the effort and sacrifices are justified only if the goal is high enough to match their expectations and desires. The wish of the participants to differentiate themselves from their peers consistently emerges in their statements. It becomes clear the importance that the youngsters of Generation Y attribute to adopt their own unique style.

The construction of the forms of subjectivation in contemporary times challenges the youngsters of Generation Y. The requirement of a constant evolution and renewal of professional and individual aspects appears as an element that threatens their psychic condition. In an attempt to respond to this demand, characteristic of the contemporary subjectivity, they can be disoriented in the vast amount of options - some of them illusory - that are available. When their psychic resources are insufficient to face this demand of the culture, more defensive postures tend to be adopted. However, the adoption of a rigid conduct can deviate the contemporary youth from a key feature of subjectivity in relation to the culture: the need to include something of the specificity of the subject.

\section{References}

Alsop, Ron (2008). The trophy kids grow up. San Francisco: Jossey Bass.

Bauman, Zygmunt (2001). Modernidade líquida. Rio de Janeiro: Zahar.

Bauman, Zygmunt (2009). Confiança e medo na cidade. Rio de Janeiro: Zahar.

Bauman, Zygmunt (2011). 44 cartas do mundo líquido moderno. Rio de Janeiro: Zahar.

Birman, Joel (1997). Estilo e modernidade em psicanálise. São Paulo: editora 34.

Birman, Joel (2006) Tatuando o Desamparo. A Juventude na atualidade. In Marta Rezende Cardoso (Org.), Adolescentes (pp. 25-43). São Paulo: Editora Escuta.

Birman, Joel (2007a). Mal-estar na atualidade: a psicanálise e as novas formas de subjetivação. Rio de Janeiro: Civilização Brasileira.

Birman, Joel (2007b). Laços e desenlaces na contemporaneidade. Jornal de psicanálise, 40(72), 47-62.

http://pepsic.bvsalud.org/scielo.php?script=sci arttext\&pid=S0103$\underline{58352007000100004 \& \operatorname{lng}=\mathrm{pt} \& \mathrm{nrm}=\mathrm{iso \& t} \operatorname{lng}=\mathrm{pt}}$ 
Birman, Joel (2013a). Sujet et pouvir dans la contemporaneité. Recherches en en psychanalyse, 15, 11-22. http://dx.doi.org/10.3917/rep.015.0011

Birman, Joel (2013b). La condition adolescent dans la contemporanéité: une lecture de la jeunesse dans la société brésilienne. Figures de la psychanalyse, 25, 63-83. http://dx.doi.org/10.3917/fp.025.0063

Birman, Joel (2013c). Os paradigmas em psicanálise são comparáveis? Sobre o mal estar, a biopolítica e os jogos de verdade. Tempo Psicanalítico, 45(1), 147-178. http://pepsic.bvsalud.org/scielo.php?script=sci arttext\&pid=S0101$\underline{48382013000100011}$

Bleichmar, Silvia (1997/2010). Un modo de pensar nuestro tiempo. In Silvia Bleichmar, La subjetividad en riesgo (pp. 19-22). Buenos Aires: Topía.

Bleichmar, Silvia (2004/2010). Límites y excesos del concepto de subjetividad en psicoanális. In Silvia Bleichmar, La subjetividad en riesgo (pp. 91-97). Buenos Aires: Topía.

Debord, Guy (1967/1997). A sociedade do espetáculo. Rio de Janeiro: Contraponto.

Dockhorn, Carolina \& Macedo, Mônica (2008). A complexidade dos tempos atuais: reflexões psicanalíticas. Argumento psicologia, 54(26), 217-224. http://www2.pucpr.br/reol/index.php/pa?dd1=2496\&dd99=view

Erickson, Frederick (1986). Qualitative methods in research on teaching. In Merlin Wittrock (Org.), Handbook of research on teaching (pp. 119-161). New York: MacMillan Publishing.

Foucault, Michel (1984). História da sexualidade 2: o uso dos prazeres. Rio de Janeiro: Graal.

Freud, Sigmund (1927/1996). O futuro de uma ilusão. In Jayme Salomão (Ed.), Obras Psicológicas Completas de Sigmund Freud Vol. XXI (pp. 15-63). Rio de Janeiro: Imago.

Gay, Peter (1988/2008). Freud: uma vida para nosso tempo. Rio de Janeiro: Zahar.

Howe, Neil \& Strauss, William. (2000) Millennials rising: the next great generation. New York: Vintage Books.

Instituto Brasileiro de Geografia e Estatística [IBGE] (2010). Recuperado de http://censo2010.ibge.gov.br/sinopse/webservice/frm piramide.php

Kehl, Maria Rita (2002). Sobre Ética e Psicanálise. São Paulo: Companhia das Letras.

Kehl, Maria Rita (2004). A juventude como sintoma da cultura. In Regina Novaes \& Paulo Vannuchi (Orgs.), Juventude e Sociedade: Trabalho, educação, cultura e participação. (pp. 89-114) São Paulo: Perseu Abramo.

Lacan, Jacques (1953/1998). Função e campo da fala e da linguagem em psicanálise. In Jacques Lacan, Escritos (pp. 238-324). Rio de Janeiro: Jorge Zahar.

Le Breton, David. (2011). Sociologie, psychanalyse et conduites à risque des jeunes. Revue du MAUSS, (1), 365-384. http://dx.doi.org/10.3917/rdm.037.0365

Macedo, Mônica \& Silva, Fernanda (2012). Inquietações no cenário contemporâneo: reflexões psicanalíticas sobre a masculinidade. In Mônica Macedo \& Blanca Werlang (Eds.), Psicanálise e Universidade (pp. 66-81). Porto Alegre: Edipucrs.

Melman, Charles (2002). L'homme sans gravité. Paris: Denoël. 
Ng, Eddy; Schweitzer, Linda \& Lyons, Sean (2010). New generation, great expectations: a Field study of the millennial generation. Journal of Business and Psychology, 25(2), 281-292. http://dx.doi.org/10.1007/s10869-010-9159-4

Potte-Bonneville, Mathieu (2004). Michel Foucault, l'inquietude de l'histoire. Paris: Presses Universitaires de France.

Prensky, Marc (2001). Digital Natives, Digital Immigrants. On the Horizon, 9(5), 1-6. http://dx.doi.org/10.1108/10748120110424816

Roudinesco, Elisabeth (2000). Por que a Psicanálise? Rio de Janeiro: Zahar.

Roudinesco, Elisabeth \& Plon, Michel (1998). Dicionário de Psicanálise. Rio de Janeiro: Zahar.

Secretaria de assuntos estratégico da Presidência da República [SAE], (2014). Social e renda. https://issuu.com/sae.pr/docs/01.nova classe $\mathrm{m}$ dia ebook

Sousa, Edson Luiz André \& Goldmeier, Paula (2008). Juventude em tempos de violência. Revista Mal Estar e Subjetividade, 8(4), 991-1020.

Stein, Joel (2013, maio). The Me Me Me Generation. The new greatest generation: why millennials will save us all. Time, pp. 25-37.

Weinmann, Amadeu (2006). Dispositivo: um solo para a subjetivação. Psicologia \& Sociedade, 18(3), 16-22. http://dx.doi.org/10.1590/s0102-71822006000300003

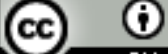 \\ Este texto está protegido por una licencia Creative Commons 4.0}

Usted es libre para Compartir — copiar y redistribuir el material en cualquier medio o formato- y Adaptar el documento - remezclar, transformar y crear a partir del material - para cualquier propósito, incluso comercialmente, siempre que cumpla la condición de:

Atribución: Usted debe reconocer el crédito de una obra de manera adecuada, proporcionar un enlace a la licencia, e indicar si se han realizado cambios . Puede hacerlo en cualquier forma razonable, pero no de forma tal que sugiera que tiene el apoyo del licenciante o lo recibe por el uso que hace. 